35 Taм же.

36 Taм же.

37 См. Уиаков Н.A. Указ. соч.- С. 29.

38 Цит. по Верещетин В.C. Международный уголовный суд: новые перспективы? // Московский журнал международного права.- 1993.- № 2.C. 6.

${ }^{39}$ См. Верещетин В.C. О работе Комиссии международного права ООН // Московский журнал международного права.- 1994.- № 1.- С. 21-35. ${ }^{40}$ См. Наумов А.B. Указ. соч.- С. 56.

Статья поступила в редакцию в феврале 1998 г.

\title{
КОНСТИТУЦИЯ АЛЖИРА 1996 ГОДА И ПРОБЛЕМА ТЕРРОРИЗМА
}

M.A. С ап ронов а*

Одной из наиболее сложных проблем политико-государственного развития целого ряда арабских стран на современном этапе стала проблема исламского экстремизма, превратившегося в общеарабскую проблему, серьезно дестабилизирующую всю обстановку в этом регионе. Наиболее отчетливо и серьезно эта проблема оказывает свое прямое воздействие на государственно-политические отношения в Алжире. Алжир последних лет превратился в своеобразный полигон, где как бы отрабатываются приемы и методы открытого противостояния государственной власти и отрядов вооруженных исламских экстремистов. Непосредственным политическим толчком к такому противостоянию в Алжире послужили события государственно-правового характера 1991 года. А начало процесса радикальных преобразований политической и социально-экономической структур государства следует отнести еще к началу 80 -х годов, когда стал набирать силу процесс демократизации алжирского общества, результатом которого явилось введение политического плюрализма и многопартийности. Это привело $\mathrm{K}$ резкому увеличению числа политических партий, претендующих на контроль за государственным аппаратом, в том числе и партий исламского направления, за короткий срок сумевших серьезно расширить свою социальную базу.

* Кандидат исторических наук, доцент кафедры востоковедения МГИМО(У) МИД РФ. 
Немало этому процессу способствовали и серьезные провалы в социально-экономической жизни Алжира, вызванные политическим курсом правящей партии Фронт национального освобождения (ФНО), что объективно привело эту партию $\mathrm{x}$ поражению на парламентских выборах в конце 1991 года. Партии исламского направления во главе с Исламским фронтом спасения (ИФС) уже в первом туре голосования нанесли очень серьезное поражение правительственной партии. Второй тур голосования мог только окончательно закрепить победу партий исламского направления во главе с ИФС. Конституционный приход к власти партий исламистов, образование нового правительства и переход Алжира к государству, построенному на принципах исламского фундаментализма, стали реальностью.

Правящий режим, опиравшийся на вооруженные силы, стал перед выбором: или уйти с политической арены, уступив место своим главным оппонентам, или принять меры чрезвычайного характера. Руководство страны избрало второй вариант. Итоги первого тура голосования были аннулированы, проведение второго тура отменено. Исламский фронт спасения был официально запрешен, что подтолкнуло фундаменталистов перейти к тактике вооруженных действий против правительства. Одновременно с этим правяший режим поставил задачу укрепления своих позиций, сформировав путем назначения Высший государственный совет (ВГС) - орган, сконцентрировавший в своих руках фактически всю полноту власти и в качестве своей основной задачи предусматривавший недопушение перехода власти в руки исламских фундаменталистов.

Эта задача сочеталась с разработкой основ новой демократической государственности. Было официально заявлено, что построение нового государства невозможно без усиления роли самого государства во всех- сферах жизни общества, искоренения насилия и терроризма в политических отношениях, обязательного учета социальнокультурных, национальных и исторических традиций страны, соблюдения прав и свобод человека. Алжирские власти в качестве основополагающих принципов приверженности демократическому и республиканскому характеру государства предложили запрещение насилия как средства прихода к власти и средства политической борьбы, уважение ислама как официальной религии Алжира, но при зтом запрещение использования религиозной пропаганды в политических целях. В долгосрочном плане для реализации поставленных целей необходима была не только выработка новой концепции строительства государственных институтов, но и ее конституционализация, что и стало одной из основных задач ВГС.

Первым программным документом, в котором через достижение "национального" согласия были официально закреплены основные положения вырабатываемой концепции, можно считать Платформу 
национального согласия ${ }^{1}$, которая стала по существу временной конституцией страны на переходный период. Платформа была утверждена на Конференции национального согласия, состоявшейся в конце января 1994 года и призванной определить направление дальнейшего государственного развития Алжира после истечения полномочий ВГС. Тогда же был сформирован Национальный переходный совет (НПС), который должен был выполнять функции представительного органа, и назначен новый глава государства. Им стал бывший министр национальной обороны Ламин Зеруаль, который был приведен к присяге 1 февраля 1994 г.

Радикальное реформирование политической системы Алжира происходило на фоне возрастающей активности исламских фундаменталистов, перешедших к практике открытого террора, прежде всего против мирного населения. Одной из целей этого вооруженного террора (за эти годы в результате вооруженных столкновений от рук исламских фундаменталистов погибло около 75 тыс. человек) было стремление доказать слабость алжирской государственной власти и, следовательно, нереальность генерального правительственного курса на достижение общенационального согласия.

Документом, юридически закрепившим основные цели построения нового государства, явилась конституция 1996 года. Новая конституция должна была кардинально реформировать всю систему государственных органов, укрепить государственную власть, а также доказать, что Алжир имеет демократический политический режим. Формально конституция 1996 года базируется на тексте старой конституции 1989 года, но с внесенными в текст основного закона коренными изменениями, касающимися прежде всего структуры и характера деятельности высших государственных органов. Фактически же это текст новой конституции, $\mathbf{K}$ тому же принятой на всенародном референдуме, то есть формально наиболее демократическим путем. Сам референдум должен был доказать всем политическим силам внутри страны и на международной арене, что алжирское руководство во главе с президентом Л. Зеруалем пользуется полным доверием и поддержкой населения, которое одобряет правительственный курс на реорганизацию всей политической системы и демократизацию общественной жизни. На референдуме за новую конституцию проголосовало 84,6 \% всех грахдан, принявших участие в голосовании. Легально действовавшие оппозиционные политические партии доказывали, что проведение референдума и принятие новой конституции в условия фактически чрезвычайного положения, нарушения прав и свобод человека, обнишания широких слоев населения, отсутствия демократических традиций волеизъявления населения могут привести лишь к усилению внутренней напряженности и конфронтации во всех областях общественно-по- 
литической жизни. Такие утверждения также способствовали усилению противостояния оппозиционных сил и правительства.

Анализ принятого на референдуме текста новой алжирской конституции позволяет сделать вывод о том, что власти добились резкого усиления авторитарных тенденций в полномочиях прежде всего главы государства - президента. Но им не удалось закрепить в тексте конституции реальные гарантии демократического характера новой государственной власти и создание подлинно демократического политического режима.

Прежде всего конституция закрепляет так называемую сверхпрезидентскую форму республики, то есть практически неограниченную и фактически неконтролируемую другими государственными органами власть президента. В руках президента в соответствии с конституцией сосредоточены самые широкие полномочия по назначению и освобождению от должности высших должностных лиц государства - главы и всех членов правительства, председателя Государственного совета, управляюшего Банка Алжира, судей, руководителей службы безопасности и других высших гражданских и военных должностных лиц (ст. 77,78$)^{2}$. Президент осуществляет прямое руководство национальной обороной, внешней политикой, заключает и ратифицирует международные договоры Алжира, принимает решение о проведении общенациональных референдумов, председательствует в Совете министров и т.д. Конститушионная сфера его полномочий огромна. Он имеет право роспуска нижней палаты парламента - Национального народного собрания, избираемого путем всеобщего голосования, назначения по своему усмотрению трети состава верхней палаты - Национального совета. Поскольку любой законопроект в парламенте требует одобрения не только нижней палаты, но и $3 / 4$ состава верхней палаты, то президент через назначаемых им депутатов может воспрепятствовать принятию любого нежелательного для него закона. Фактически исполнительная власть в лице правительства и судебная власть в лице Верховного суда полностью подконтрольны главе государства. А избранный путем всеобщего голосования президент не может быть досрочно отстранен с должности ни избирателями, ни каким-либо государственным органом. Таким образом, в центре всей системы государственных органов поставлен президент Алжира, обладающий почти неограниченными полномочиями.

Парламент как законодательный орган во многом носит характер подчиненного главе государства института. И хотя его контрольные функции распространяются на сферу правительственной деятельности и могут даже выражаться в вынесении правительству вотума недоверия, но вопрос об отставке правительства решает в окончательном виде только президент. Законодательные полномочия в 
форме издания президентом законодательных указов могут быть делегированы ему парламентом на период парламентских каникул, перерыва между сессиями, а также в период чрезвычайного или осадного положения, вводимого также президентом (ст. 124). Таким образом, это делегированное законодательство еще больше усиливает полномочия президента, фактически ставя его над всеми ветвями государственной власти.

Что касается формального объема конституционных прав и обязанностей алжирских. граждан, то он довольно обширен. В специальной главе IV "O правах и свободах" конституция декларирует равенство граждан перед законом, запрещение дискриминации по любым основаниям, а также обязанность государства способствовать эффективному участию всех граждан в политической, экономической и других сферах общественной жизни (ст. 29, 31). Конституция гарантирует всем алжирцам осуществление и зашиту основных гражданских и политических прав и свобод: неприкосновенность личности, свободу совести и свободу выражения мнений, зашиту частной жизни и достоинства человека, тайну переписки, неприкосновенность жилища, свободу проведения собраний, создание общественныХ объединений и т.д.

Интересны конституционные положения о роли политических партий. Конституция признает право граждан на создание и функционирование политических партий, которое может быть ограничено, если партия покушается на основные права и свободы человека, национальное единство, безопасность государства, его демократический характер и т.д. Партиям запрешено прибегать к насилию или другим принудительным действиям для достижения своих целей. Необходимо отметить, что конституция запрещает создавать партии на религиозной основе, хотя по той же конституции ислам закрепляется в качестве государственной религии, а президент обязательно должен быть мусульманином. Запрещение создавать партии на религиозной, расовой или региональной основе ставит фактически вне сферы политической деятельности не только экстремистские исламские группировки, но и большинство оппозиционных партий. Следует отметить, что новая алжирская конституция в определенных аспектах носит довольно противоречивый характер. С одной стороны, она создает основу для национальной консолидации, для экономического развития, что отражено в статьях о сильной президентской власти, определенном объеме конституционных прав и свобод человека, который при условии их действительной гарантированности и реальном осушествлении на практике мог бы потенциально обеспечить демократическое развитие Алжира. Но, с другой стороны, эти же фактически неограниченные полномочия президента, а также сама структура, порядок формирования и пол- 
номочия парламента, ставящие его в откровенно зависимое от президента положение, делают проблематичным эффективную деятельность парламентской оппозиции и любых неправительственных партий, что явно противоречит идее правового государства, о котором упомянуто в тексте конституции как о важнейшем принципе (преамбула).

Наконец, сами конституционные права и свободы граждан во многом носят декларативный характер, не опираются на серьезную социально-экономическую базу, на развитые демократические институты в условиях низкой степени правового и политического сознания значительной части населения, традиционно сильных позиций ислама во всех сферах обшественной и государственной жизни. Все это не создает прочной юридической основы для реального осушествления основных прав и свобод граждан, защиты их личной безопасности, физической и духовной целостности.

Кроме того, конституционные нормы о сильной президентской власти в стране, раздираемой серьезными внутренними противоречиями, совсем не гарантируют адекватное ее осуществление на практике, а часто откровенно демонстрируют прямую слабость институтов власти в попытках противостоять внутригосударственному терроризму. И в этих условиях конституционные гарантии безопасности граждан, их личных прав и свобод оборачиваются неприкрытой фикцией, а сама конституция перестает быть действующим документом.

В конце декабря 1997 года внутригосударственный террор исламских фундаменталистов в Алжире достиг своего апогея. Убийства среди мирного крестьянского населения, особенно на востоке страны, приняли массовый и угрожаюший характер. Убийства происходили даже в священный для мусульман месяц рамадан. Это не могло не взволновать европейскую обшественность. Алжир в срочном порядке посетила делегация Европейского Союза в составе высокопоставленных представителей Великобритании, Австрии и Люксембурга. Уже само ее прибытие в Алжир, пусть и с ограниченными полномочиями и на короткий срок (всего 24 часа), можно расценивать как отказ руководства Алжира от определенной самоизоляции, в которой он оказался в связи с непрекрашающимся вооруженным противостоянием между властями и религиозными экстремистами.

Делегашия обсудила с алжирским руководством в лице министра иностранных дел Алжира Ахмедом Аттафом комплекс вопросов, в частности проблемы безопасности населения, права человека в Алжире, установление более тесного сотрудничества между Алжиром и Европейским Союзом. Делегация имела возможность встретиться с представителями легальной алжирской оппозиции и редакторами алжирских газет. Основной итог визита нашел свое 
отражение в докладе, представленном "тройкой" в конце января 1998 года в Брюсселе на встрече глав внешнеполитических ведомств стран - членов Европейского Союза. Европейским странам в качестве рекомендации этого совещания было предложено усилить дипломатическое давление на алжирское руководство, с тем чтобы вынудить его сесть за стол переговоров с “интегристами”, выступающими против применения насилия хак способа разрешения внутриполитического конфликта. Здесь следует отметить, что данная рекомендация носит довольно общий характер, так как в ней отсутствует четкое определение сил, которых авторы доклада именуют “интегристами". Более того, подобные переговоры уже были проведены властями Алжира не только с лидерами умеренных исламских партий "Ан-Нахда" и Движение обшества за мир (ДОМ), но и с некоторыми представителями руководства запрещенного Исламского фронта спасения и командованием его вооруженного крыла Исламской армии спасения (ИАС). Их итогом стало перемирие, объявленное ИАС с 1 октября 1997 г. Кроме того, 69 представителей ДОМ и 34 депутата от партии “Ан-Нахда” вошли в первый в истории Алжира парламент, образованный на многопартийной основе в составе 380 депутатов. После проведения выборов в соответствии с конституцией 1996 года было сформировано новое правительство Алжира. Нз общего количества министерских портфелей (39) семь мест в коалиционном правительстве получила партия ДОМ, что прямо подтверждает умение и желание властей находить компромисс с представителями умеренного крыла исламизма. Что же касается представителей крайнего исламистского движения, которые в период легального сушествования ИФС относились к его радикальному крылу, то сейчас они действуют в составе Вооруженной исламской группы (ВИГ). После объявления перемирия они вышли из так называемого исполнительного комитета ИФС за рубежом и образовали собственный Координационный совет ИФС. Но вести с ними переговоры алжирскому руководству невозможно по той простой причине, что они сами категорически против любых контактов с властями. Поэтому, по всей видимости, данные рекомендации “тройки" являются в создавшихся условиях нереальными. Совершенно очевидно, у Европейского Союза нет пока единого, четко обозначенного подхода к оценке событий в Алжире.

Напряженность и противоречивость характеризуют и американскую политику в отношении Алжира. Официальные представители Вашингтона, с одной стороны, высказывали мнение, что действия алжирской армии "соответствуют понятию правового государства", а с другой - выдвигали требования к руководству Алжира допустить в страну международные миссии для проведения расследований об обстоятельствах массовых убийств мирного населения. 
В этих условиях алжирское руководство твердо решило, что любое иностранное вмешательство в виде инспекций только всколыхнет новую волну насилия со стороны исламских экстремистов. Взяв курс на силовое искоренение крайне правых при одновременном сотрудничестве с “умеренными” исламистами, алжирские власти считают, что это чисто внутренние проблемы страны. Руководство Алжира категорически отказалось принять от Европейского Союза гуманитарную помощь и какую-либо комиссию, высказавшись только за развитие сотрудничества в области борьбы с терроризмом.

Совершенно очевидно, что внутренние проблемы алжирского государства могут быть решены только на путях общенационального согласия, тем более что курс на вооруженное решение проблемы исламского фундаментализма в Алжире является, по всей видимости, бесперспективным. По некоторым оценкам, партии фундаменталистского направления могут опираться примерно на треть алжирского населения, что подтверждается результатами выборов в Национальное народное собрание (парламент) Алжира, состоявшихся 5 июня 1997 г., на которых партии умеренного исламского толка Движение общества за мир и “Ан-Нахда" заняли второе и четвертое места соответственно, набрав в общей сложности около $42 \%$ от числа проголосовавших.

Попытки международного сообщества, в том числе и упомянутой делегации, оказать международное влияние на решение чисто внутренних проблем Алжира тоже не представляются достаточно удачными. Кардинальное решение проблемы исламского фундаментализма объективно перерастает в общеарабскую проблему и, видимо, лежит в региональных совместных усилия х арабских стран по обузданию террористических групп, действующих в различных странах. Наиболее сложная проблема, связанная непосредственно с прекращением внутригосударственного террора на современном этапе, затрагивает не только Аіжир. Проявления исламского экстремизма могут возникнуть и в других арабских и мусульманских странах. Решение ее может иметь серьезное международное значение и, возможно, станет одной из нанболее трудноразрешимых проблем начала следующего тысячелетия.

1 Journal officiel de la Republique Algerienne Democratique et Populaire (traduction française), Alger, 29 janvier 1994.

2 Constitution de la RADP du 28 novembre 1996 (Ministère de l'environnement), Alger, 1996.

Статья поступила в редакцию в декабре 19972. 